\title{
CULTURA SAMPLEADA EN LA BABEL CONTEMPORÁNEA. NOTAS SOBRE LA COLONIZACIÓN Y DEPREDACIÓN COMO PRÁCTICAS DISCURSIVAS
}

\author{
SAMPLED CULTURE IN CONTEMPORARY BABEL. \\ NOTES ON COLONIZATION AND DEPREDATION \\ AS DISCOURSIVE PRACTICES
}

\author{
José Manuel TRABADO CABADO \\ Universidad de León \\ jose-manuel.trabado@unileon.es
}

\begin{abstract}
Resumen: En este artículo se trata de analizar las relaciones que establecen las diferentes prácticas discursivas dentro del mundo audiovisual contemporáneo y la influencia que unas ejercen en otras formando parte de lo que podría venir a denominarse como cultura sampleada. La red de relaciones se hace cada vez más densa y los textos se saturan de significado en un complejo proceso que obliga al receptor a construir una lectura que va siempre más allá del propio texto para dar sentido a los mensajes. Todo ello se ejemplifica en el caso del spot televisivo de la compañía telefónica española Movistar que se valió de discursos precedentes. Algunos hablaron de plagio, pero la cadena de relaciones era mucho más larga de lo que indica un parecido evidente entre dos discursos. Cómo se modifican la esencia, las intenciones comunicativas y contextos pragmáticos es el objeto de análisis de estas páginas.
\end{abstract}

Palabras clave: Anuncio. Vídeo-clip musical. Animación. Vídeo viral. Sampleado. Versión musical. Fotografía.

Abstract: This article attempts to analyze the relations established by the various discursive practices found in the audiovisual world and the influence some of these strategies exert on each other within what could be known as sampled culture. The network of connections in this complex 
process becomes increasingly tangled and the texts saturate with meaning, thus forcing the receivers to construct a reading which always goes beyond the text itself in order to confer meaning on the messages. All this can be specifically illustrated by a TV commercial spot produced by the Spanish telephone company Movistar which made use of previous discourses. Although some people considered it plagiarism, the chain of connections was indeed much more intricate than that merely showing an evident similarity between two discourses. How the essence, communicative purposes and pragmatic contexts of these texts are modified is the object of analysis of the following pages.

Key Words: Commercial. Vídeo-clip. Animation film. Viral video. Sampling. Cover. Photography.

En el año 2008 Telefónica lanzó un spot televisivo para promocionar su paquete de teléfono más internet (DUO) que adquirió popularidad debido a la ingeniosa estrategia audiovisual exhibida. La sencillez de medios empleados ocultaba una idea conceptual de gran rendimiento. Todo consistía en dos manos cerradas que a través de diversos movimientos dejaban visibles distintos mensajes compuestos por las palabras que estaban escritas a lo largo de su anatomía. Su gesticulación ofrecía una coreografía perfectamente sincronizada con el ritmo musical que servía a modo de performance introduciendo variaciones visuales que venían a crear un contrapunto con la monotonía derivada del uso de un único plano a lo largo de todo el spot televisivo. De forma inmediata los blogs más activos se encargaron de señalar el profundo parecido (hablaban directamente de plagio) que poseía con un vídeo viral colgado en YouTube. Ese vídeo es conocido como "Daft Hands" y, efectivamente, la idea viene a ser la misma. Al margen de que el anuncio publicitario, que fue realizado por Ramsés Albiñana para DDB España, siga muy de cerca la idea de un vídeo colgado en Internet por un usuario anónimo lo interesante reside en que este hecho se inscribe en una cadena mucho más larga en la que se puede observar una constante transformación y regeneración de

${ }^{1}$ El vídeo se colgó en junio de 2007 y en enero de 2019 lleva casi setenta millones de visitas. Esta es la url: https://www.youtube.com/watch? $v=K 2 c Y W f q-N w$ [20/11/2018]. 
mensajes que tienen lugar dentro de la esfera audiovisual y que de forma transversal recorre y afecta a distintos formatos y soportes. La polémica generada en torno a ese innegable parecido quizás desviase la atención de todo el proceso, mucho más complejo, de travestimiento y absorción de unos mensajes por otros haciendo hincapié en el problema del hurto y la falta de originalidad publicitaria. Encontrar una fuente tan cercana parecía arrojar cierto descrédito sobre uno de los puntales del mundo publicitario: la creatividad. No extraña, pues, que la inmediatez que propicia la Red buscase el tono polémico y evitase entrar en un proceso reflexivo que no acabaría de encajar con la filosofía del post de los diversos blogs, que buscan más la frescura de ideas que la sistematización de un pensamiento elaborado.

Sin embargo, quizás convenga retrotraer todo el proceso creativo y hacer mención de los diversos estadios por los que atraviesa un texto audiovisual determinado en un momento de recursividad casi ilimitada. En todo ello se podría observar la reubicación constante a la que ha sido sometido un texto determinado dentro del sistema comunicativo. Lo que nació en el terreno artístico acabó inscrito dentro del terreno publicitario, pero fue necesaria toda una serie de intermediarios que lo modificaron y añadieron elementos que serán fundamentales en las nuevas recreaciones del mismo. Entramos en el dominio de una cultura sampleada que conecta con la idea de la cultura líquida elaborada por Bauman ${ }^{2}$ y en cuyo seno adquieren sentido prácticas como el remix (Manovich, 2005 y 2007; Knobel y Lankshear, 2011) ${ }^{3}$, la postproducción (Bourriaud 2005', Rodríguez

\footnotetext{
2 "La nuestra es una sociedad de consumo: en ella la cultura, al igual que el resto del mundo experimentado por los consumidores, se mantiene como un depósito de bienes concebidos para el consumo, todos ellos en competencia por la atención insoportablemente fugaz y distraída de los potenciales clientes, empeñándose en captar esa atención más allá del pestañeo [...] El principio del elitismo cultural es la cualidad omnívora: sentirse como en casa en todo entorno cultural, sin considerar ninguno como el propio, y mucho menos el único propio" (Bauman, 2013: 19).

3 "El remix se hace patente en todos los ámbitos de la práctica cultural, incluyendo las conversaciones cotidianas; de hecho 'la cultura es un remix' [...]. En el sentido más amplio, el remix es la condición general de las culturas: sin remix no hay cultura" (Knobel y Lankshear, 2011: 107).

4 "In this new form of culture, which one might call a culture of use or a culture of activity, the artwork functions as the temporary terminal of a network of interconnected elements, like a narrative that extends and reinterprets preceding narratives. Each exhibition encloses within it the script of another; each work may be inserted into different programs and used for multiple scenarios. The artwork is no longer an end point but a simple moment in an infinite chain of contributions" (Bourriaud, 2005: 19-20).
} 
Fernández 2012) o el "produsage" (Bruns 2007 y 2008)5. Los entornos digitales han ayudado a desarrollar la convergencia entre autor/productor y receptor a la vez que los mensajes son reelaborados continuamente en una cadena que se antoja infinita ${ }^{6}$. En esos tránsitos discursivos los prejuicios no existen y los lenguajes establecen alianzas asimétricas en lo que parece un murmullo infinito.

Ese comportamiento asimétrico podría concretarse en una doble tipología de los discursos atendiendo a su forma de actuar ${ }^{7}$. Por un lado, podría establecerse un tipo de actividad discursiva capaz de saltar a otros lenguajes e integrarse en nuevas estructuras aportando un valor extra y ayudando a conseguir un significado más complejo. Se caracterizaría por su fuerza productiva; vendría a ser un modo de uso concebido como energeia y actuaría como una espoleta de los procedimientos recursivos a través de los cuales se puede re-generar continuamente un discurso. Podría denominarse a estas prácticas prácticas discursivas colonizadoras. La música sería un perfecto ejemplo en este sentido por su capacidad para adaptarse a otros estilos a través de versiones, samplers, etc. y por su posibilidad de integrarse en otras estructuras de carácter audiovisual como anuncios publicitarios, vídeo-clips, películas, espectáculos teatralizados, etc. Frente a esta dinámica podrían verse otro tipo de prácticas que no son invasivas, tal y como se acaba de apuntar anteriormente, sino que obedecen

\footnotetext{
5 "In the context of online user-led content creation environments ranging from open source through to massively multiplayer online roleplaying games, the idea of content production may need to be challenged: the description of a new hybrid form of simultaneous production and usage, or produsage, may provide a more workable model" (Bruns, 2007: s. p.). Para una mayor profundización en este concepto remito a Bruns (2008: 9-36). Sobre la aplicación de este término a nuevos lenguajes y el proceso creativo de la fan fiction, Flickr, música remezclada, mashup en YouTube, etc. (Bruns, 2008: 227-258).

6 'Recientemente la convergencia entre las denominadas 'nuevas tecnologías' (medios digitales) y los 'nuevos valores' (el crecimiento generalizado de actividades y comunidades en línea de carácter colaborativo) ha permitido que los principios que rigen el remix musical se extiendan a diversos formatos audiovisuales. Esto ha provocado también una 'crisis' entre quienes ostentan los derechos de copyright y de propiedad intelectual, tanto de la industria como particulares" (Knobel y Lankshear, 2011: 106).

${ }^{7}$ Suscribo las palabras de Rodríguez-Ferrándiz cuando afirma: "Cultural experience was, before, a circumscribed activity, exclusively applied to an object and therefore intense and almost intimate. Meanwhile, today a valued cultural experience is one that does not seem to fix its attention on particular point, unraveling it in detail, but rather, it follows a trajectory which jumps from one point to another, stopping at any specific point only long enough to gather momentum to move on the next interconnected point" (2012: 407).
} 
a un impulso contrario: absorben e integran en su perímetro cualquier otro lenguaje para convertirlo en parte de su ADN. Su naturaleza le da una fuerza fagocitadora: son prácticas discursivas predadoras: la publicidad ${ }^{8}$ vendría a ser una práctica discursiva que se nutre de los más variados procedimientos para elaborar sus mensajes. El carácter de energeia se ve aminorado y frena en cierta manera esa recursividad tan habitual en el zoco de la Babel contemporánea. En cierto modo podría plantearse la pregunta de si la publicidad no actuaría con una poética esterilizante: es difícil encontrar anuncios que den lugar a otros anuncios y, si los hay, el número es mucho más reducido que con cualquier otro discurso. Se podría aventurar alguna explicación como el hecho de que la publicidad une mensajes a marcas y estas actúan como un coto vedado. Un simple eslogan como "Just do it" actúa como una frontera que delimita un coto vedado. El bien comunal del lenguaje se convierte en propiedad privada. Sólo puede reutilizarse a modo de parodia que encubra una deconstrucción de signo ideológico.

La polémica del plagio del anuncio de Telefónica hizo visible un eslabón de la cadena de sampleados tan habitual en la época contemporánea: en cierto modo se clamaba contra esa política de apropiación típica de las prácticas discursivas predadoras de un recurso libre —un vídeo viral de YouTube - en un espacio desterritorializado: la red. Lo anecdótico de esta polémica sirve como coartada para ejemplificar parte del funcionamiento de esta cultura sampleada. Bajo esa punta de iceberg se oculta un proceso de mayor alcance en la que se pueden constatar ejemplos de funcionamiento de lenguajes colonizadores y de lenguajes caníbales. Los anuncios publicitarios actuarán como un tipo de lenguaje terminal que no genera, al menos en este caso, nuevos discursos. El vídeo viral en el que se basaba se convirtió, por el contrario, en una referencia que sigue siendo recordada como una efeméride y la música que se usó como base sonora sigue mostrando su vitalidad al ser nuevamente versionada e integrada en nuevos mensajes.

\footnotetext{
${ }^{8}$ Tomamos la publicidad como un lenguaje perfectamente legitimado dentro del entramado cultural. Véanse las interesantes reflexiones que a ello le dedica Rodríguez Ferrándiz (2008) que me eximen de una explicación pormenorizada. Quisiera también destacar sus palabras sobre las posibles diferencias entre publicidad y productos industrial-culturales que se realizan en ese mismo texto (2008: 29-30. Nota 22).
} 


\section{DE LA MÚSICA SAMPLEADA AL ANIME EXPERIMTAL: FORMAS DE COLONIZACIÓN DISCURSIVA}

\subsection{Cuando la música se mira en el espejo: la práctica del sampler}

El afán polémico y la contundente acusación de plagio sobre una compañía conocida es un buen punto de entrada en las prácticas de la cultura sampleada. Toda esta historia podría iniciarse con la mención a la canción "Cola Bottle Baby", del cantante Edwin Birdsong, que este incluyó en el disco homónimo Edwin Birdsong de 1979. Esta canción se hizo mucho más visible desde el momento en que el dúo francés de música electrónica Daft Punk sampleó esta canción para hacer su "Harder, Better, Faster, Stronger", incluida en su disco Discovery, publicado en el 2001. La letra supone una reducción casi de índole minimalista porque lo verdaderamente importante es la consecución de un sonido. La distorsión de la voz y el ritmo hipnótico hacen de la canción algo fácilmente identificable. Todo ese disco de Daft Punk está compuesto por canciones que samplean otros temas musicales previos. Supone en cierta manera iniciar los fundamentos de absorción de una palabra ajena para ser integrada en el discurso propio, algo que se va a repetir en la regeneración de este mensaje a través de diversos medios. Bajtín denominó a esto dialogismo y Julia Kristeva prefirió utilizar un término que alcanzó un mayor éxito: intertextualidad ${ }^{9}$. Daft Punk construyó ya su mensaje sobre otros. Sirva esto para derribar el principio de originalidad que pueda ser esgrimido como idea para desmontar la efectividad de un anuncio publicitario. Tampoco esto es algo que deba sorprender. El mundo musical ha usado diversas estrategias que sirven para crear conexiones entre los diversos mensajes. Si la técnica del sampleado es algo más cercano a determinados tipos de música como el rap, el hip hop o la música electrónica ${ }^{10}$ no puede pasarse por alto el hecho

\footnotetext{
${ }^{9}$ Desde un punto de vista histórico sobre el aspecto de la intertextualidad es útil el libro compilado por Peter Jaszi (1994). También puede consultarse el trabajo de Marko Juvan (2008). Obviamente, el proceso de intertextualidad es un proceso creativo que va más allá del hecho literario. Para más detalles "Intertextuality in the Non Literary Acts", en Grahan Allem (2000: 174 y ss.). Especialmente interesantes son las páginas "Pastiche in Visual Arts", en Hoestery Ingebord (2001: 16 y ss.). Para la intertextualidad literaria recuerdo el trabajo de José Enrique Martínez Fernández (2001) y la compilación de textos llevada a cabo por Desiderio Navarro (1997).

${ }^{10}$ Así se expresa Virgil Moorefield: "The tracks used need not be originals; hip-hop was the first form
} 
de que, dentro del universo del pop-rock, las versiones o covers de ciertos temas estén a la orden del día. A buen seguro todo el mundo recuerde versiones musicales que, a la vez que homenajean, borran la canción original (Sweeting, 2004; Plasketes, 2010). No es la versión musical la única práctica dialógica en el universo pop-rock. La tendencia a volver al pasado para recuperar estilo y maneras parece ser también una constante dentro de estos estilos musicales según advierte Simon Reynolds (2012). El sampleado de canciones no deja de ser igualmente otra práctica dialógica a través de la cual un artista construye una base musical sobre la que empezar a generar su voz. El caso de Daft Punk no tiene nada de extraordinario. La integración de otros sonidos y melodías en una actualización supone un acto de apropiación, pero también de reinvención. Sobre ese esquema rítmico melódico normalmente se sitúa una letra que no tiene nada que ver con el mensaje de la primera canción utilizada. Por otro lado, una versión o el sampleado de una canción puede actuar a modo de caballo de Troya que trae a un primer plano una canción olvidada o relegada a ocupar un lugar secundario. La incorporación a través del sampleado o la versión de esa canción supone una nueva oportunidad para encontrar un público que se sorprende del redescubrimiento de tesoros olvidados.

\subsection{Integración y narrativización del discurso musical}

Lo que sí supone una profunda innovación por parte de Daft Punk es la inserción de todas y cada una de las canciones del disco Discovery en un contexto audiovisual inesperado: me refiero a la película de animación titulada Interstella 5555 del año $2003^{11}$. Fue creada por los estudios japoneses de Toei y dirigida por Kazuhisa Takenouchi bajo la supervisión de Leiji Matsumoto. Las canciones se integran en el mismo orden en el que aparecen en el disco y forman lo que podría considerarse una especie de musical bajo la estética del anime japonés. Tanto es así que no existe diálogo alguno, sino que todo el elemento sonoro está saturado

of popular music in which the wholesale appropriation of someone else's track became standard, if not always accepted, practice" (2005: 90). La relación de la técnica del sampleado con el hip-hop es subrayada por frases como la que sigue: "In musical terms, sampling began with hip-hop, before samplers even existed" (2005: 91). Son interesantes también las observaciones y tipología de los remixes musicales que hacen Knobel y Lankshear (2011: 113-114).

${ }^{11}$ Para una panorámica sobre este aspecto Ian Inglis (2011). 
por la aparición de esas canciones que se integran ahora en un universo visual de estética japonesa y de contenido narrativo. Los diversos temas musicales, que nacieron de forma individual, vienen a afianzar ahora, al participar como banda sonora del anime Interstella 5555, un carácter orgánico al pertenecer a una estructura más compleja que los engloba y les da un sentido que quizás originariamente no tuvieron ${ }^{12}$. El anime japonés ofrece una relectura narrativa del disco Discovery. Sin embargo, en la inserción de esas canciones dentro de la película de animación existen fluctuaciones entre usos cercanos al vídeo-clip y otros que acentúan más el componente narrativo. Canciones como "Digital Love" y sobre todo "Something about us" integran perfectamente sus letras dentro de los engranajes narrativos de la película. Junto con esa integración narrativa que supone una recontextualización de la letra musical que pasa a pertenecer a las vicisitudes narrativas en las que se ven envueltos los personajes de la película existe otra forma de integración del elemento musical de Daft Punk en el anime. Esta otra fórmula de integración se da en mayor medida en los momentos musicales puramente instrumentales, tales como "Crescent Dolls". La ausencia del elemento vocal permite la utilización de la música como una forma de sutura de diferentes momentos temporales. La música propicia entonces una recuperación de diversas secuencias que en términos narrativos podrían funcionar como un sumario de acontecimientos unidos bajo una unidad de tono emocional que viene dado por el elemento musical. Esta integración desconfigura el tiempo

\footnotetext{
${ }^{12}$ Esto nos lleva a una pequeña reflexión sobre la forma de ensamblar canciones en la música popular contemporánea. Indudablemente ha dependido del soporte de grabación: disco de vinilo, musicasete, $\mathrm{CD}$, etc. que influía en la organización del material: orden y cara a la que pertenecían (aunque esto último ya era irrelevante en el CD). Con el paso al mundo digital la estructura del LP puede dejar de tener sentido ya que las canciones pueden comercializarse de forma individual. Por ello el mundo digital amenaza la estructura formal del álbum musical. Existieron, no obstante, formas organizativas que buscaban una coherencia narrativa como, por ejemplo, el álbum conceptual en el que se sitúan hitos como Sargent Peppers Lonely Hearts Club Band y que tuvo en la obra de David Bowie, Pink Floyd, The Who y otros grupos claros ejemplos (Shute, 2015). Siguiendo con estas formas narrativas dentro de lo musical existen en la escena contemporánea ejemplos de enorme interés. Pienso en la práctica del grupo español Dorian que ha rodado una trilogía de vídeoclips musicales con una continuidad narrativa en la que se utilizan las canciones "La tormenta de arena", "Paraísos artificiales" y "La mañana herida" pertenecientes al álbum La ciudad subterránea de 2009. Existe una recomposición narrativa de parte del álbum musical conseguida por medios audiovisuales. Por otro lado, puede recordarse la estructura narrativa que Rosalía da a su disco El mal querer amparándose supuestamente en la narración occitana del siglo XIII titulada Flamenca. Cada canción constituye un capítulo y el disco se deja leer bajo una nueva perspectiva.
} 
narrativo estilizándolo, volviéndolo irreal en un acto de rememoración que difumina las referencias cronológicas exactas. No es un tiempo narrado sino evocado y la nebulosa de la memoria se vale de la música como disolvente de los férreos condicionamientos temporales de la narración.

La canción "Harder, Better, Faster, Stronger" se sitúa más bien dentro de esa incorporación de la música con tintes narrativos y en la que no se atisba ningún ejemplo de distorsión temporal. La secuencia narrativa que acompaña a esta canción representa el momento en el que el grupo musical extraterrestre que protagoniza la película, tras haber sido raptado por el malvado habitante de la tierra Darkwood, es convertido a la raza humana tras haberle suplantado la memoria original por otra que les haga creer que siempre han sido humanos. Tanto la imaginería como la temática de esta secuencia se incardinan de lleno dentro de la matriz genérica de la ciencia ficción y no dista tanto, desde un punto de vista argumental, de lo tratado con asiduidad por autores como Philip K. Dick y la modificación artificial de la memoria y los recuerdos.

En todo caso, llama la atención que la película instaure una lógica narrativa donde no era predecible, lo que supone una influencia de lo cinematográfico sobre la estructura musical del disco Discovery, pero no deja de ser interesante que los diferentes temas musicales actúen sobre la película pautando sus secuencias narrativas. Cada canción sirve de marco que crea un tono para desarrollar cierta anécdota argumental. Dicho de otro modo, parece como si la película organizase sus motivos narrativos en torno a las diferentes canciones, lo que invita a pensar en una estructura cinematográfica construida sobre un esquema musical previo que condiciona su propio devenir argumental. Cine y música se prestan sus mecanismos expresivos estableciendo un proceso de influencia mutuo. Interstella puede ser entendida como una unión de diversos vídeo-clips musicales con continuidad argumental pero también como una película de animación cuya banda sonora se basa en las canciones que conforman el disco Discovery. Si la película inscribe en el álbum musical una relectura narrativa, podría decirse que, por su parte, el tempo narrativo cinematográfico viene marcado por un metrónomo musical.

Un aspecto que distanciaría a Interstella de la poética del vídeoclip es el hecho de que, frente a lo que viene siendo habitual en este género audiovisual, el protagonismo no recae sobre los autores de la música. Existe un desplazamiento que desvincula la noción cantante / autor (música) de 
la de protagonista (cine). Ambas se funden normalmente para el caso de vídeo-clips narrativos. Aun desarrollando el componente narrativo, en Interstella 5555, no sucede esto ${ }^{13}$. Existen varias formas deliberadas de ocultación de la figura de cantante / autor. Por un lado, se sustituye a Daft Punk por un grupo de extraterrestres que forman, además, un banda de pop/rock. Con ello se permite la fusión del elemento musical con el de la ciencia ficción. Por otro lado, cuando los componentes del dúo Daft Punk aparecen en la película, lo hacen en un pequeño cameo que sucede durante la secuencia narrativa en la que suena la canción "Crescent Dolls". Se narra allí la recogida de un premio musical por la integrante femenina de ese grupo de extraterrestres convertidos en humanos. Uno de los nominados que compiten por ese premio con "Crescent Dolls" (así se llama el grupo extraterrestre) es precisamente Daft Punk. Estos aparecen con su clásico disfraz de robots, lo que supone, también, otra forma de ocultación. En las actuaciones en directo, así como en las entrevistas Daft Punk utilizan siempre esa máscara que es un signo de identidad, pero también de desaparición. Esta forma de reaparecer dentro del discurso narrativo visual de la película de animación responde más a las prácticas cinematográficas que a las de la poética del vídeo-clip.

Podría emparentarse esa doble forma de ocultación en el discurso cinematográfico (cameo / máscara) con lo que sucede en el plano musical. Al menos cuatro de los temas musicales de Discovery se basan en canciones previas que han sido sampleadas. Las que no poseen un referente previo también utilizan un proceso creativo colectivo en el que participan otros artistas. Son, en suma, estrategias en las que el autor como individuo identificable y singular queda difuminado, convertido en una figura borrosa que encaja perfectamente con la poética del remix y el sampler que ejecutan en el apartado musical.

El discurso planteado en Interstella 5555, arriesgado en su propuesta expresiva, queda, sin embargo, normalizado con el final sorprendente que posee la película. Tras toda la peripecia de fugas, rescates, héroes salvadores que perecen y son recordados por su pueblo, amores frustrados, etc. el final opera una suerte de normalización narrativa que explota, sin embargo, el elemento sorprendente. Toda la historia que acabamos de

\footnotetext{
${ }^{13}$ Para todo lo concerniente a la función de actor en el vídeo-clip, así como la conexión entre la poética del vídeo-clip con la estética cinematográfica, véase Carol Vernallis (2004: 54-72).
} 
ver como espectadores es en realidad el resultado de la imaginación de un niño que jugaba con sus muñecos al tiempo que escuchaba el disco de Daft Punk. Al final del día, sus padres lo acuestan y paran el disco. Se reconfigura así el universo narrativo ficcional de la película. Toda la secuencia narrativa es el resultado de la actividad lúdico-imaginativa del niño. La banda sonora provenía del disco que el niño escuchaba. Así, pues, existe una revisión de lo narrado que ahora es visto de una perspectiva que aporta una mayor verosimilitud narrativa al tiempo que genera el efecto sorpresa en el receptor. Por otra parte, la reintroducción de Daft Punk, aunque sea de forma metonímica, al mostrar su disco sonando, sirve para recuperar la noción de autoría y fijar así el discurso musical al dúo francés. Lo que verdaderamente sucedía no se ve hasta la parte final que actúa a modo de epifanía que explica retroactivamente, como sucede en parte de las narraciones fantásticas, las anomalías que sembraban el discurso de extrañeza.

\subsection{La colonización musical de la animación: vanguardias narrativas}

La práctica, sin embargo, de unir el lenguaje de la animación y el elemento musical no es tampoco algo extraordinario. Baste recordar ejemplos como los vídeo-clips de Alan Parson Project "Don't answer me" (que supone una traducción de los mecanismos del cómic al mundo del clip musical) o A-ha "Take on me" (que utilizaba la técnica de la rotoscopia), por no mencionar el largometraje protagonizado por los Beatles con su Yellow Submarine (1968). Es, sin embargo, dentro de la industria japonesa precisamente donde los estudios $4^{\circ} \mathrm{C}$ han incidido de forma asidua en las relaciones entre anime y música buscando la vanguardia más experimental. En 2006 crearon cuatro cortos de animación reunidos bajo el título genérico de Amazing Nuts. Pueden ser definidos como vídeos musicales basados en el lenguaje de animación. Todos ellos superponen sobre el tema musical de varios artistas pertenecientes a la compañía de discos Avex un contenido narrativo que desarrolla una historia de amor. Su duración está en torno a los 10 minutos, lo que los apartaría de lo que, en esencia, constituye el formato estándar del vídeo-clip musical. Esa duración es un buen indicador formal del carácter innovador propuesto por estos cortos musicales. El proyecto surge como una colaboración entre el estudio de 
animación y diversos artistas musicales. No existe, pues, esa prevalencia habitual de la música (como algo ya dado) a la que hay que poner imágenes en su conversión de canción a vídeo-clip. Surgen como resultado de un proyecto conjunto y simultáneo que deriva en un formato experimental $\mathrm{y}$, a la vez, versátil. Como corto de animación incorpora en él un tema musical. El corto, de apenas 10 minutos, lleva inscrito un clip musical que ocupa casi la mitad de su duración. Se trata de un producto híbrido que posee unas características narrativas nítidas que son, sin embargo, desdibujadas en el momento musical. Ese carácter anfibio (narración / clip musical) será el que propicie una doble realización de estos cortos ya que existen versiones más breves que sólo muestran el momento musical con lo que pueden ser entendidos como cortos narrativos o vídeo-clips musicales. También se albergó el proyecto de desarrollar estas breves narraciones en forma de largometraje, con lo que el corto asumiría la función de tráiler cinematográfico. Ya sea como corto, como clip musical o como tráiler potencial, el carácter experimental de la fusión música/anime creó un formato híbrido que poesía una capacidad camaleónica desde un punto de vista funcional. Su decodificación difiere tan sólo con alterar algunos elementos que pueden ser fácilmente suprimibles.

Otra muestra del carácter rupturista de estos estudios de animación en los que se observa la fusión de música y anime es el caso de Fluximation (2005). Se trataba de breves cortos musicales que ponían imagen a cada uno de los temas del disco de la cantante nipona Hikaru Utada titulado Exodus. Apenas duraban un poco más de medio minuto y estaban pensados para ser descargados en el teléfono móvil. No se trata, pues, de un video musical al uso ya que no recoge toda la canción; diseña una estrategia muy relacionada con el marketing que poseía por naturaleza el formato del clip musical. Esos mecanismos publicitarios se acentúan gracias a un proceso de depuración y concentración temporal: funcionan estos cortos como anticipos, pequeños resúmenes de las canciones que se apoyaban en la animación para ser también visibles. Son spots publicitarios y parecen ajustarse, en consecuencia, a esa duración. El cambio de plataformas acarrea una mutación formal. Lejos quedan los aproximadamente cuatro minutos de los clips musicales convencionales que se emiten por TV; los nuevos soportes, como el teléfono móvil, buscaban otra forma de relación con el público: los cortos musicales de Fluximation actúan a modo de pequeñas píldoras que abren el apetito, pero sin colmarlo. 
Otra buena muestra de la rica y compleja relación que existe entre la animación japonesa y la música es el caso de los Anime Music Video Music $(A M V)$. Son vídeos realizados por fanáticos de determinadas series que escogen algunos de sus momentos más vibrantes desde una perspectiva emocional y los subrayan a través de una doble estrategia. Una, que tiene que ver con el principio de selección que recorta y yuxtapone esos momentos de intensidad melodramática $\mathrm{o}$, al menos, de cierta relevancia temática, $\mathrm{y}$, otra, relacionada con el hecho de acoplar una canción que busque crear la atmósfera y el tono adecuado para canalizar todo ese caudal de afinada emotividad. Se inscriben estas prácticas dentro de lo que Lawrence Lessig (2008: 77 y ss.) ha definido como una cultura RW (Read and Write) en la que los receptores se convierten en nuevos creadores y que opone a las maneras de la cultura RO (Read Only) que esboza un receptor mucho más pasivo ${ }^{14}$. Son también muestras del lenguaje creativo que operan en el seno de ciertas comunidades que se identifican y se agrupan en torno a la devoción por una serie o una película convirtiéndola en una serie de culto. Esas comunidades que han creado lo que Jenkins denomina la Cultura de la Convergencia ${ }^{15}$. El resultado no deja de ser una lectura personal que edita una narración para componer imágenes que aglutinen una sensación. El resultado será luego compartido en portales como YouTube y sirve para reforzar los lazos comunitarios de todos aquellos fans que reconozcan los fragmentos seleccionados y sepan de su valía afectiva. No extraña, pues, que bajo la melodía de "Mortal Weapon" del grupo Matthew Good Band se antologuen secuencias de la serie de Naruto o de Bleach, o que, curiosamente, la canción de Leonard Cohen "The Famous Blue Raincoat"

\footnotetext{
${ }^{14}$ En consonancia con este pensamiento están las palabras de Henry Jenkins y su término de cultura participativa: "El término 'cultura participativa' contrasta con nociones más antiguas del espectador mediático pasivo. Más que hablar de productores y consumidores mediáticos como si desempeñasen roles separados, podríamos verlos hoy como participantes que interaccionan conforme a un nuevo conjunto de reglas que ninguno de nosotros comprende del todo" (Jenkins, 2008: 15). La idea de un receptor activo que produce un nuevo mensaje remezclando materiales previos es algo ya aceptado dentro de los estudiosos de los medios digitales, como viene a demostrar Ola Erstad: "The main point is that more and more people in our culture can take part in these remixing activities; not only an elite or specific groups" (2008:185).

15 "Con 'convergencia' me refiero al flujo de contenido a través de múltiples plataformas mediáticas, la cooperación entre múltiples industrias mediáticas y el comportamiento migratorio de las audiencias mediáticas, dispuestas a ir casi a cualquier parte en busca del tipo deseado de experiencias de entretenimiento" (Jenkins, 2008: 14). Este concepto ha sido desarrollado y aplicado al fenómeno de YouTube por Jean Burgess and Joshua Green (2009).
} 
sirva como marco emocional en el que situar las escenas de la serie anime Nana en el vídeo "The Trouble" colgado igualmente en YouTube. La música refuerza el intimismo y busca la complicidad de los fans de la serie con los que se comparte ese álbum de recuerdos y, también, de sensaciones ${ }^{16}$.

Así, pues, ya sea en el marco de la experimentación de estudios japoneses o en un amplio espacio de la cultura de convergencia en la que anónimos usuarios editan sus series de culto para convertirlas en un fetiche cuyo afectos y efectos se agudizan por la mediación de la música elegida, la animación y la música establecen sólidas relaciones que actúan en la misma línea de Interstella 5555. Si bien existía un proceso de neutralización de la anomalía narrativa conformado por ese final que explicaba lo extraño del asunto, también puede acudirse a una tradición, aunque sea formada a posteriori, que sirve para legitimar ese experimento músico-narrativo del anime japonés que narraba el disco de Daft Punk.

\section{EL VÍDEO VIRAL COMO INTERMEDIARIO ENTRE EL ARTE Y LA PUBLICIDAD: CUANDO LA MÚSICA SE CON- VIERTE EN PERFORMANCE}

Ese proceso de recreaciones del mensaje iniciado con el sampleado de Daft Punk de ciertas canciones y la posterior integración en una estructura fílmica tiene cierta continuidad en otras prácticas como la formación de un vídeo viral accesible a través de Internet y que en el 2007 obtuvo un gran éxito. Un anónimo usuario - otra forma de ocultación- creó un vídeo utilizando como base musical precisamente el "Harder, Better, Faster, Stronger" de Daft Punk ${ }^{17}$. Su idea fue sencilla pero eficaz. Unos puños

\footnotetext{
${ }^{16}$ El libro de Pelle Snickars y Patrick Vonderau ofrece una buena colección de ensayos sobre YouTube (2009). Puede verse también Michael Strangelove (2010).

${ }^{17}$ Sería interesante establecer una relación entre estas prácticas y el fin del vídeo-clip tal y como lo conocemos. Gianni Sbilla señala: "Music Videos were one of the most interesting things that happened in the media landscape of the eighties and the nineties. However, the 'golden age' of the music video is long gone, and the Internet has caused the end of the music videos as we know them. But new videos are born again in a new form and in a new space: YouTube" (2010: 225). Llega así a la conclusion que merece ser señalada: "In the digital space, the music video becomes a "viral tool" "y "the musicians get closer to their fans, giving them the opportunity to manipulate and remix their music starting from the master-footage the original material" (2010: 230). Puede verse el interesante artículo de Carol Vernallis incluido en el mismo volumen que estudia la transformación
} 
cerrados al abrirse de diferentes modos dejaban a la vista mensajes que coinciden con la letra de la canción. La coreografía de las manos está perfectamente sincronizada con la música creando así una performance que poseía además un valor redundante pues mediante su actuación repetía visualmente lo que se puede oír. Música e imagen vuelven a establecer un acoplamiento perfecto. Todo ello venía posibilitado por el hecho de que la letra de Daft Punk era absolutamente minimalista y en la que la repetición de rimas propiciaba que con un simple gesto se pudiese transformar una palabra en otra.

La letra de la canción reza como sigue:

Work It / Make It / Do It / Makes Us / Harder / Better / Faster / Stronger / More Than Hour / Our / Never /Ever / After / Work is / Over [x2]

La sencillez de la letra y sobre todo su carácter rítmico se adecua muy bien al esquema musical repetitivo de la música electrónica de Daft Punk. Existe, por así decirlo, una traducción de la rítmica discursiva a la música electrónica que, ahora en el seno del vídeo viral, será reconvertida a un mensaje visual.

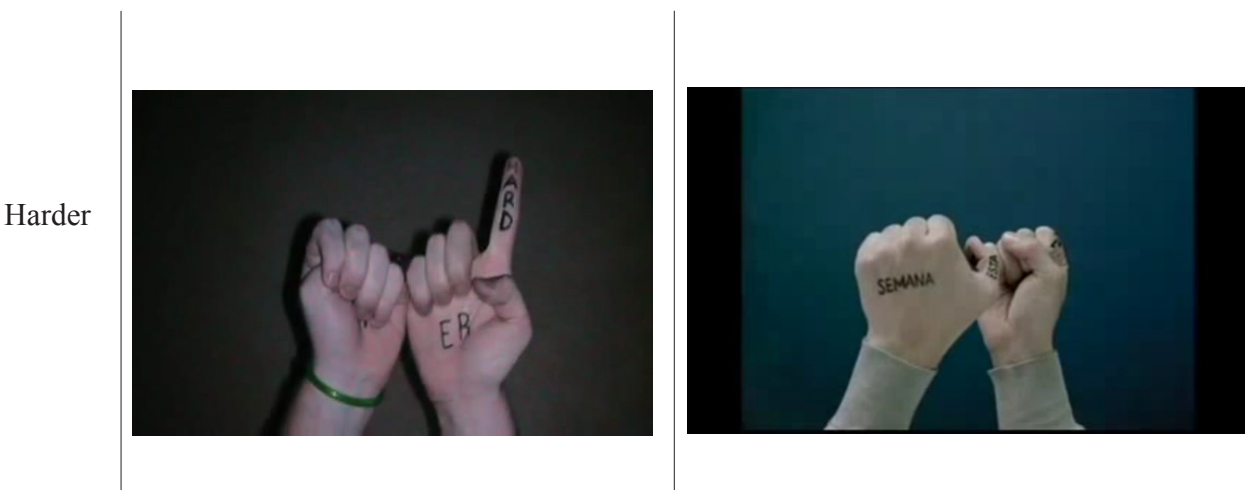

de los vídeos musicales debida a la influencia de YouTube (2010). 


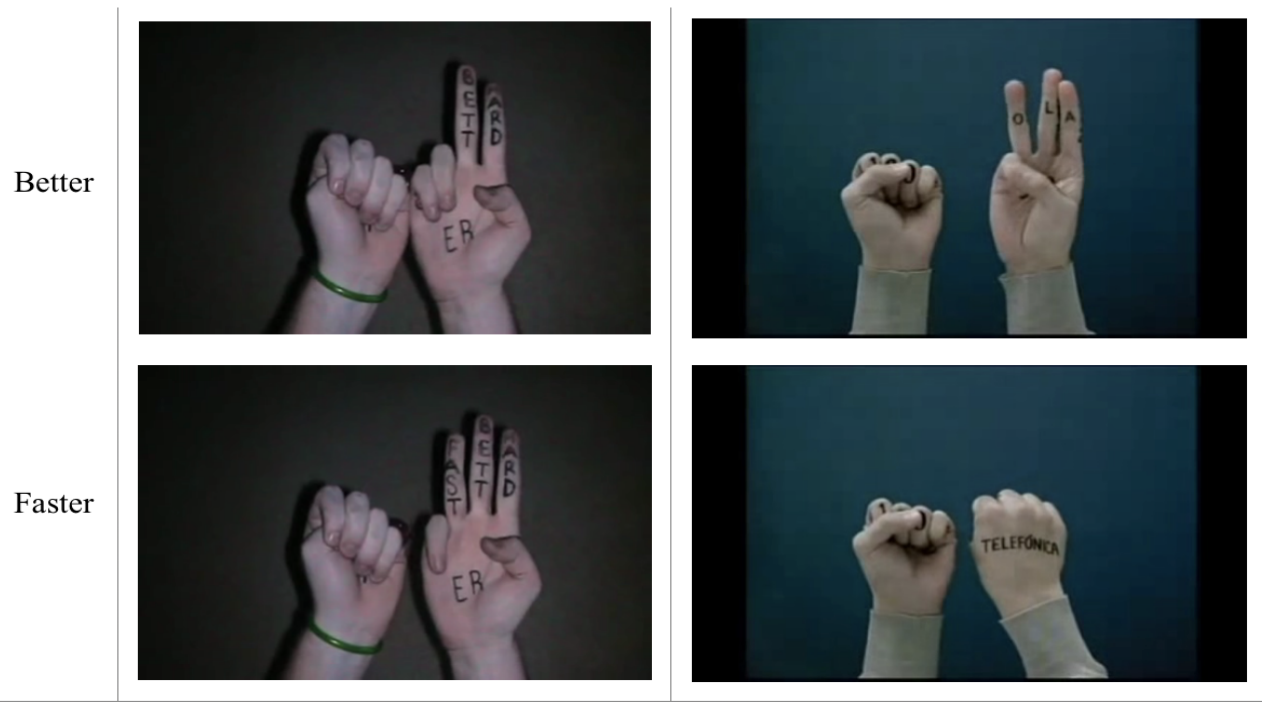

Letra del vídeo viral (col. izquierda), planos del vídeo dafthands (col. centro) y planos anuncio dúo de Telefónica (col. derecha)

La simplicidad del mensaje y la repetición de sonidos permitían establecer una matriz a partir de la cual generar todos los menajes. De haber sido algo más complejo, la utilización de las manos hubiera sido inviable.

No hay que obviar que, de igual manera a lo visto en las transformaciones previas en las que la figura del autor quedaba borrosa, existe también en este caso una voluntad de ocultación no sólo ya por el carácter anónimo del mensaje colgado en la red sino también porque, desde un punto de vista visual, se borran las marcas de identidad y autoría. Esto mismo se repetirá en otras recreaciones de este famoso vídeo como el que lleva por título Daft Bodies en el que no sólo se muestran las manos sino también el cuerpo de dos muchachas cuyos rostros han sido velados ${ }^{18}$.

En este caso la canción de Daft Punk no funciona como parte

\footnotetext{
${ }^{18}$ Convendría recordar el ejemplo de Sophie Merry que protagoniza una serie de vídeos denominados "Groovy Dancing Girl” en su canal de YouTube Bandy Toaster. En 2007 grabó un vídeo bailando precisamente la canción "Harder, Better, Stronger". Pronto se convirtió en un vídeo viral. En febrero de 2019 llevaba más de seis millones de visualizaciones. Se puede concluir que en 2007 fue el año de viralización digital de la canción de Daft Punk y lo hizo a través de vídeos de la plataforma de YouTube y por usuarios que no tenían relación directa con los autores de la canción.
} 
integrante de un conjunto mayor. Su estrategia es la de la singularización. No persigue tampoco unos fines artísticos serios, sino que se decanta más bien por desarrollar un espíritu más cercano a la diversión y el humor. Sin embargo, creó una fuerte capacidad icónica que fue tenida en cuenta más allá de los anónimos usuarios de la Red. El cambio de plataforma y soporte, así como los nuevos espacios comunicativos que propicia Internet reconfiguran los comportamientos de los receptores que se muestran como parte activa y con capacidad para apropiarse de los mensajes y devolverlos transformados. El receptor ha añadido un suplemento visual a un mensaje sonoro que decide además compartir y poner a disposición de los demás invitándoles en cierto modo a disfrutar de él, desacralizándolo por un parte, e incitando a continuar con una práctica que no difiere en exceso de los remixes y sampleados de la música electrónica, sólo que pasándolo a un lenguaje audiovisual. No existe un producto acabado, todo puede volver a ser recreado y cada receptor es potencialmente un nuevo creador que puede tamizar los mensajes que le llegan para desmontarlos, recontextualizarlos y re-producirlos porque ahora posee un espacio de expresión sin intermediarios que es Internet.

Pasamos, pues, de la música en cuanto que actividad artística a la inserción en el cine de animación, que continúa dentro de esos linderos que podemos seguir denominando arte, a otra forma de expresión más espontánea y menos regulada por las instituciones. El vídeo viral se sitúa en un terreno de nadie y no posee una serie de instrucciones claras de cómo ha de ser entendido. Ese borrado de los indicadores contextuales facilita el traslado de lo que nació como arte para ser reabsorbido por otros discursos como el publicitario que nunca han tenido inconveniente en fagocitar ni estrategias retóricas ajenas ni mensajes previos que no habían nacido con el fin publicitario ${ }^{19}$. En un mundo en el que impera el mercado y con un espacio como Internet que diluye los contextos informativos de los mensajes que actúan como indicadores orientativos para el receptor es fácil suponer que en ese comportamiento viral el vídeo podía ser apropiado para fines comerciales. Todo puede ser reconvertido para desempeñar una función de marketing. En consecuencia, los publicitarios echaron mano de esa estrategia retórica audiovisual del vídeo viral para realizar

${ }^{19}$ Para abundar en el aspecto intertextual publicitario remito a Raúl Rodríguez / Kiko Mora (2002: 47-87). 
un spot publicitario que, por llamar también la atención, despertó pronto las conciencias que llamaron la atención sobre su falta de originalidad. La coreografía de las manos y la distorsión del sonido acercan mucho el anuncio de Telefónica a ese vídeo viral llamado "Daft Hands" hasta el punto de que es perfectamente comprensible la actitud de crítica mostrada por foros y blogueros. El criterio de originalidad preside de forma implícita esas quejas y cada uno tiene la libertad de establecer los parámetros de su gusto estético. Sin embargo, la cadena de influencias se había iniciado ya con los propios Daft Punk que habían sampleado esa canción creando una inercia de la que puede hacerse eco ese vídeo viral. El usuario anónimo sacó del terreno del Arte la canción de Daft Punk, regulado por las instituciones, para situarlo en un lugar de indefinición como es la Red. Eso permitía una apropiación por parte del mundo publicitario que resitúa ese mensaje volviéndolo a unas reglas de codificación reconocibles. $\mathrm{Su}$ duración de apenas treinta segundos sigue un estándar que persigue ajustarse a las parrillas televisivas. El mensaje nuevo sí posee ahora un protocolo de funcionamiento claro. El receptor sabe cuál es el propósito y es capaz de desvincularlo de cualquier intención artística. La distancia entre "Harder, Better, Faster, Stonger" de Daft Punk y el anuncio del Dúo de Telefónica de 2008 realizado por Albiñana Films para DDB España es, desde un punto de vista pragmático, muy grande y sólo explicable si nos atenemos a la mediación del famoso vídeo viral. Las remodelaciones en la función comunicativa son profundas: del arte se pasa a la indefinición y, más tarde, a la publicidad. El proceso de autoría se complica porque, junto con el cambio de formatos, canales de transmisión, etc. se da un proceso de autoría de creciente complejidad porque unos autores se esconden, otros se borran gradualmente recreando, usurpando, reaprovechando en beneficio propio y hasta "hurtando"20, si se quiere, formas expresivas previas. Entretener, divertir, vender son propósitos que se van solapando sobre los mensajes que ofrecen huellas de cómo han sido usados.

\footnotetext{
${ }^{20}$ Se ha señalado la importancia de un término como appropriation. Para más detalles remito a John Welchman (2001) y Deborah Root (1996). Quiero destacar las palabras de Julie Sanders cuando diferencia entre apropiación y adaptación: "The gesture towards the source text(s) can be wholly more shadowy [...], and this brings into paly, sometimes in controversial way, questions of intellectual property, proper acknowledge, and, its worse, the charge of plagiarism" (2006: 32). Véase el conjunto de ensayos editados por D. Evans (2009).
} 


\section{EL SAMPLEADO TIENDE A INFINITO}

La historia no acaba, sin embargo, aquí. La canción de Daft Punk ha sido nuevamente sampleada por el rapero Kanye West para su tema "Stronger" incluido en el álbum Graduation (2007)21. No sólo se incorpora la música sino también se realiza una relectura de la letra que toma sólo uno de los elementos presentes en la canción del dúo francés: Stronger. El mensaje, apenas existente en la canción de Daft Punk, se subvierte al introducir una nueva filosofía basada en la perseverancia de las propias convicciones y la asunción de sus errores. Al mismo tiempo integra un elemento amoroso / carnal, un discurso de urgencias ("I need you right now" dice la canción) que ofrece nuevos derroteros temáticos. No sólo música y letra entablan una relación dialógica con la canción de Daft Punk. El vídeo-clip, realizado por Hype Williams, constituye un complejo entrelazado de referencias en las que ocupan un lugar de privilegio las realizaciones visuales que de la canción había hecho ya Daft Punk. El vídeo-clip de "Stronger" posee varios registros pseudo-narrativos que articulan diferentes códigos visuales. No puede verse una narración íntegra. En todo caso se atisban fragmentos que invitan a ser leídos como vestigios de una narración descoyuntada. Carreras de motos en un escenario urbano, escenas en un hospital en la que una enfermera se asusta al ver el estado de un paciente, policías de élite, etc. son datos que invitan a reconstruir una narración avocada a sugerir una inercia que no acaba de concretarse ni de desarrollar una lógica perceptible por el receptor. En esas incursiones narrativas director y cantante han pretendido de forma deliberada realizar un homenaje a la película de anime, Akira, de Katsuhiro Otomo. Las

\footnotetext{
${ }^{21}$ Hay ejemplos posteriores que retoman la canción de Daft Punk. Tal es el caso del anuncio de televisión creado en 2013 para el Audi A3 Sportback que usa la canción como banda sonora y cuyo lema "Faster, Louder, Smarter, Lighter, Farther, Safer" muestra una influencia de la letra de la propia canción del dúo francés. Muestra de la vitalidad de la canción y su recorrido por diversas plataformas está el hecho de que en julio de 2016 la cuenta de Tweeter Pokemon Go Albacete subió un videomontaje con la música de Daft Punk usando los Pidgeys de Pokemon Go. En 2017 un anuncio de televisión de la compañía Intuit Quickbooks en su campaña Backing you usó como banda sonora una versión que realizó la jovencísima cantante angelina Willa Amai (apenas 13 años tenía en ese momento). La música electrónica da paso a una balada intimista que invita a la melancolía. Todo ese principio de recursividad infinita está íntimamente ligado con la modularidad defendida por Manovich (2005) en la que los lenguajes complejos pueden ser desmontados en piezas que pueden ser ensambladas de nuevo.
} 
escenas del escaneado del vídeo-clip son muy cercanas en su realización visual a las utilizadas en Akira.

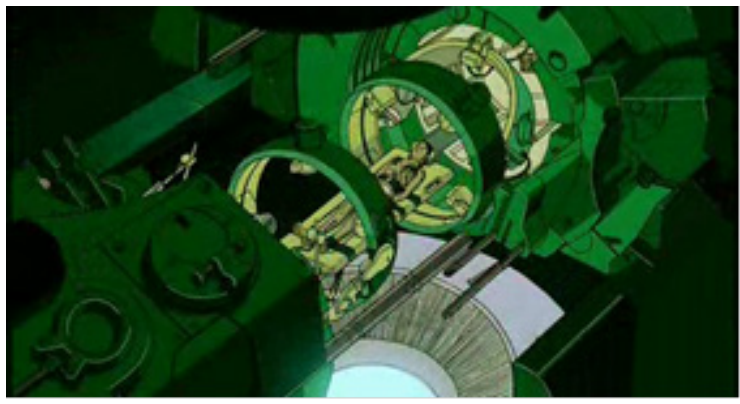

Fotograma de Akira

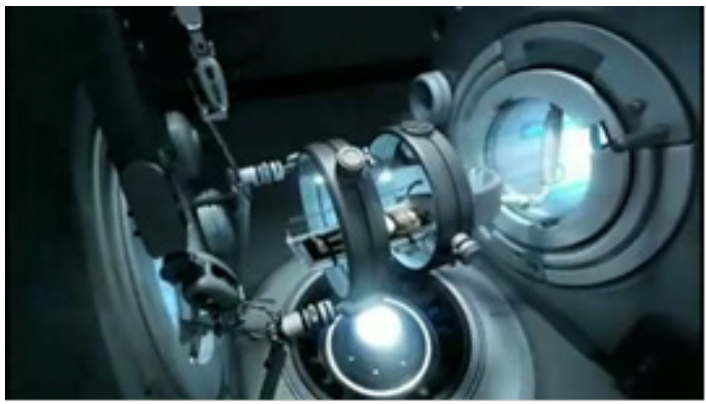

Fotograma de Stronger

El vídeo-clip fue rodado en Tokio y el homenaje al imaginario nipón es claro tanto en las referencias intertextuales visuales a una película de culto dentro del mundo de la animación como a la integración de la megalópolis llena de neones que crean el escenario en el que situar los atisbos narrativos del clip musical ${ }^{22}$. No sólo hay que tener en cuenta el referente claro de Akira. Es posible pensar que la propia realización de la película de Interstella 5555 haya servido como un acicate a la hora de aunar la música con el campo temático de la ciencia-ficción. Si se recuerda la secuencia narrativa en la que precisamente se insertaba la canción de "Harder, Better, Faster, Stronger", que es la base que samplea West para su canción, se observa que allí existe otra escena de escaneado de cuerpos y transformación en humanos. Si desde un punto de vista visual los referentes de Akira son claros, no deja de ser sugerente pensar que el punto de unión entre la canción sampleada y el lenguaje de la animación japonesa sea precisamente Interstella 5555. Esto explica que en el clip musical aparezcan las figuras de dos robots que parecen controlar el proceso de escaneado de Kane West. Su apariencia visual clona el aspecto que tiene el grupo Daft Punk que eligen esas máscaras robóticas para sus actuaciones.

\footnotetext{
${ }^{22}$ Para un análisis detallado del estilo de Hype Williams dentro de un contexto postmoderno y su poética del pastiche como marca formal es de interés el trabajo de Roger Beebe (2007).
} 


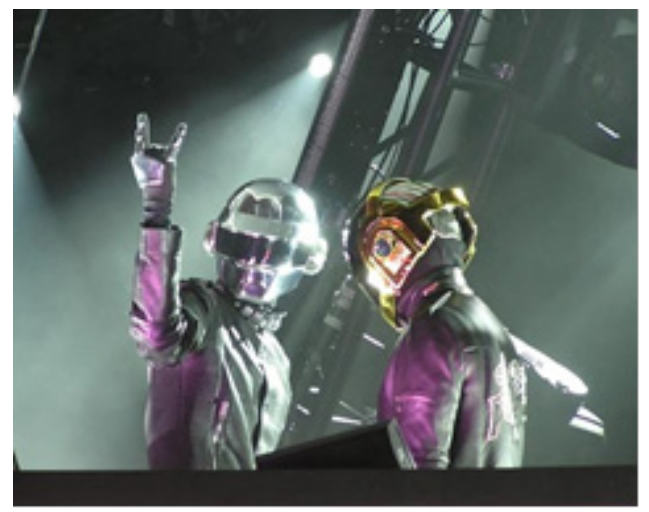

Imagen de Daft Punk en un concierto

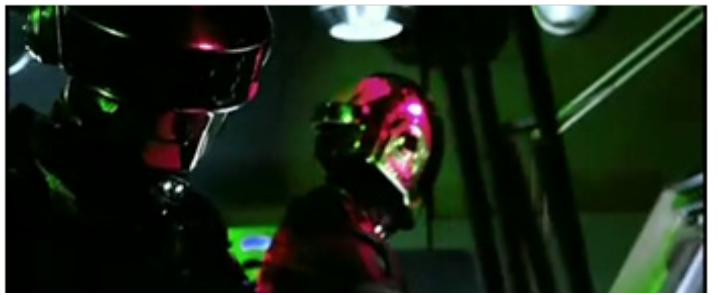

Fotograma del vídeo-clip "Stronger”, dirigido por Hype Williams.

Fruto de esta dialéctica entre el dúo francés y el rapero norteamericano será la actuación conjunta en la ceremonia de entrega de los Grammys de 2008 en la que West interpreta precisamente "Stronger". Por supuesto, cuando aparecen con su mesa de mezclas lo hacen parapetados bajo sus atuendos robóticos. Lo que se inicia como un diálogo musical pasa a ser también una relación dialógica en lo visual que amplía el campo de referencias a otros textos (como Akira) y acaba derivando también en una colaboración escénica en la que el elemento espectacular y teatral subrayan toda la realización musical.

La canción de Kanye West fue versionada, más tarde, por el grupo estadounidense 30 Seconds to Mar, convirtiéndola en una balada al rebajarla en su tempo musical y en la que apenas existen distorsiones melódicas típicas del sampleado y de la música de base electrónica. El sampleado se reconvierte en una versión musical provocando una readaptación de las prácticas intertextuales. Cada tipo de música parece especializar, en consecuencia, sus propias formas de establecer relaciones dialógicas. El rock prefiere la versión musical en tanto que el rap y la música electrónica buscan más el remix y el sampleado como formas de integrar discursos ajenos en el propio. Son formas diferentes de absorción de lo ajeno para convertirlo en propio ${ }^{23}$. No basta con esto, en el tráiler del

${ }^{23}$ Para un estudio de la apropiación en la música véanse las páginas de James Young (2010). Términos 
juego de tenis para PC Top Spin 4 se reutiliza la canción de "Stronger" de K. West. También aparece dentro de la banda sonora de la película Never Back Down. Lo que nació como un sampler de otro sampler se convierte en vídeo que usa guiños al anime japonés y que puede convertirse en una balada en manos de un grupo de rock o en la banda sonora del spot de un videojuego. Los contextos comunicativos se debilitan permitiendo apropiaciones, recreaciones y nuevas versiones de mensajes que son reutilizados hasta el infinito con propósitos muy diferentes. Basta con agregarles nuevos códigos visuales, musicales, etc. para establecer un nuevo mensaje hipercodificado. De la música al cine o, a los vídeos virales en tierra de nadie, pasando por la publicidad para regresar de nuevo a la música o ser nuevamente arrastrado al terreno del marketing publicitario o formar parte de una banda sonora cinematográfica. Son los tortuosos caminos de los menajes en la Torre de Babel de los nuevos medios. Las retóricas son maleables, los intermediarios invisibles en muchas ocasiones, el proceso de autoría se ve diluido porque el mensaje se impone y borra las marcas de origen y la información contextual. Todo puede funcionar para un propósito que no estaba previsto. Surge una cultura que remezcla y reaprovecha voces y discursos para generar nuevos mensajes.

Quienes hablan de plagio en el caso del anuncio de Telefónica insisten sólo en dos estadios de una cadena más amplia y compleja en la que canciones e imágenes son recreadas en un proceso que interpreta la recepción sólo como un primer paso hacia la re-creación. La cercanía tanto de la música como de la gestualidad de las manos ofrecía una prueba más que suficiente para demostrar la irrefutable relación entre ambos. Existe implícito un criterio de originalidad como algo a seguir dentro de la creación que es asumido por quien habla de plagio. Sin embargo, en ese proceso evolutivo mostrado aquí a grandes rasgos que arrancaba de la canción de "Cola Bottle Baby" y llega al anuncio de un videojuego de tenis intervienen muchos procesos cercanos a esta práctica. Sin embargo, términos como cover o sampler parecen haber legitimado culturalmente y ¿económicamente? dentro del mundo musical la absorción y homenaje de voces diferentes. Las prácticas acaso no difieran tanto en lo estético, aunque sí pueden existir profundas diferencias en el uso y rentabilidad económica. Obviamente desde esta perspectiva hay que admitir que el rendimiento del

como variación en la música clásica y sampleado en el hip-hop son una suerte de apropiaciones. 
clip viral "Daft Hands" es muy diferente al que pudo haber obtenido DDB España por realizar este anuncio de telefónica. La singularidad del anuncio de televisión pudo, por otra parte, facilitar el conocimiento del clip viral a muchos nuevos receptores e iniciar así una activación retroactiva que llevaría al telespectador a conocer un dúo de música electrónica francés, a un cantante poco famoso que colaboraba como músico de Stevie Wonder, llamado Edwin Birdsong o llegar hasta casos del anime japonés como Interstella 5555 o Akira. La entrada a ese proceso de continua recreación se puede hacer por muchas puertas posibles. El espectador, quizás sin saberlo, llega a una compleja organización rizomática en la que es difícil sino imposible entrever centros y establecer una sólida cronología en un proceso de extenuante intertextualidad ${ }^{24}$.

\section{CLIPS MUSICALES, ANUNCIOS Y FOTOGRAFÍAS: LAS PUERTAS GIRATORIAS DEL ARTE EFÍMERO}

Otro caso en el que un anuncio de Telefónica seguía pautas creativas muy cercanas a otras realizaciones audiovisuales previas es el que sirvió para anunciar la campaña de Adsl en el verano de 2009. Allí unos muchachos hacían surf y se sumergían en el mar para, luego, remontar el vuelo con una cometa. La técnica utilizada es la de la animación basada en el stop-motion y lo singular de su ejecución visual es la elección de la perspectiva. Situada la cámara en una posición cenital se ofrece una especie de engaño visual al trasladarse la perspectiva arriba-abajo a una simulación frente-fondo. Ese reconocimiento del artificio que el espectador identifica y disfruta supone todo un placer visual que ayuda a la fácil memorización del pequeño relato de animación esbozado en el anuncio.

\footnotetext{
${ }^{24}$ Una situación como la anteriormente señalada puede explicar el caso de canciones como "Somebody that I used to know" del cantante Gotye. Su trasformación de artista indie en un cantante mainstream podría relacionarse, por su supuesto no de forma exclusiva, por la versión que de esa canción hizo la banda canadiense Walk off the Earth y, sobre todo, por la llamativa ejecución musical que mostraban en pantalla al aparecer todos los miembros del grupo interpretando la canción tocando una única guitarra. El vídeo en YouTube posee en enero de 2019 más de 185 millones de visualizaciones. Pudo actuar como un estimulante eficaz para captar la atención y remitirla al original de la canción de Gotye. Además, la canción se incluyó dentro de la serie Glee lo que provocó un aumento exponencial del público que llegaba a esa canción. Dentro de esta red de conexiones no hay un proceso lineal de trasmisión sino múltiples circuitos de circulación en el que las influencias son multidireccionales.
} 
En este caso se ha indicado otra fuente cercana que utiliza básicamente los mismos procedimientos retórico-visuales. Se trata del vídeo-clip musical del polifacético israelí Orien Lavie realizado para su canción "Her Morning Elegance". La técnica de stop-motion y la perspectiva cenital ofrecen pruebas de ese parecido razonable. Los blogs que identificaron este parecido inmediatamente lo situaron de nuevo en el terreno del plagio. Tenían ya la coartada del precedente del anuncio Manos para mostrar cómo volvían a repetir el mismo procedimiento.

Sin embargo, conviene situar en un marco explicativo otros elementos para delimitar la complejidad del asunto de si se trata de un plagio sin más o de reelaboraciones de varios mensajes previos. En este caso es necesario aludir a la obra del fotógrafo Jan von Holleben y su serie de fotografías iniciadas en el 2002 titulada Dreams of Flying. La perspectiva visual utilizada es la misma que la que usa Orien Lavie en su vídeo y el spot de telefónica. Algunas de las fotografías sí que parecen haber sido prácticamente reproducidas en el spot de telefónica ${ }^{25}$. Pueden verse planos como el de la cometa que arrastra al protagonista del spot y le hace volar o como el del buceo en el mar cerca de un cofre que contiene un tesoro que son muy cercanos a fotos de Holleben. El propio Holleben ha realizado algunos cortos de animación basándose en las técnicas de animación del stop-motion como el titulado The Bird que suponen una expansión narrativa de lo indicado en sus fotos.

\footnotetext{
${ }^{25}$ De hecho, pueden verse los numerosos homenajes a sus fotos que el propio Von Holleben recopila en su web en el apartado "who we inspire".
} 


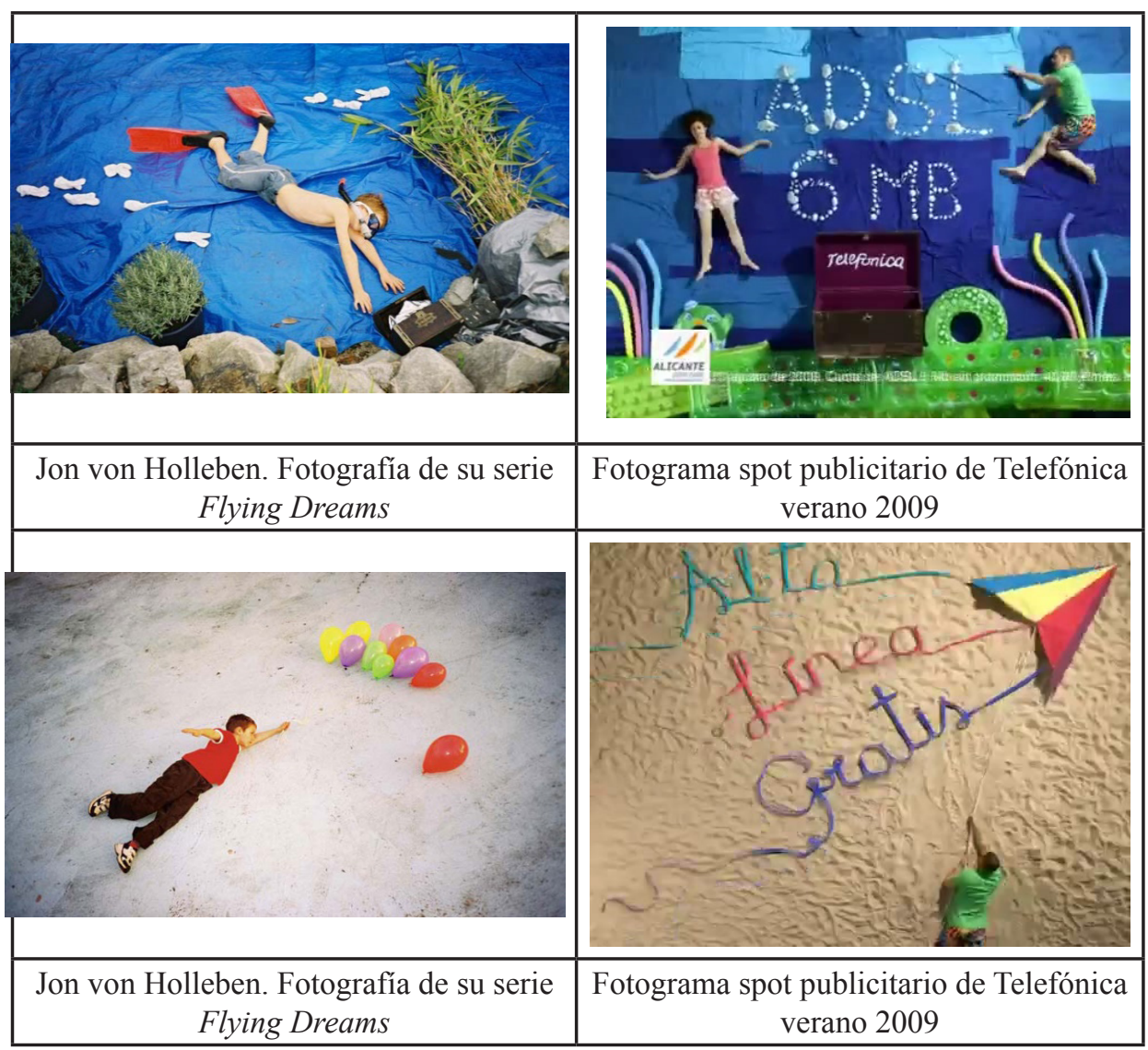

Para quienes hablan de otro plagio de Telefónica en su spot, prima el hecho de utilizar la misma técnica de animación y la misma perspectiva. Inciden más en los procedimientos retórico-visuales que en los temáticonarrativos. El universo fantasioso y el engaño visual estaban ya presentes en el fotógrafo alemán que ha realizado incluso un vídeo-clip musical para el grupo irlandés Bell X1 "The Ribs of a Broken Umbrella" (canción perteneciente al disco Blue Ligths on the Runaway publicado en 2009) utilizando también esas mismas técnicas del spot-motion y la perspectiva cenital.

Orien Lavie sigue esos mismos parámetros técnicos pero la historia difiere mucho en su contenido de lo esbozado por Holleben, primero, y 
Telefónica, más tarde. Narra la vida diaria de una joven: su despertar, su caminar por la calle, sus viajes en tren y sus sueños. Lo mágico de su realización visual y narrativa reside en el hecho de la multiplicación funcional del espacio. En un alarde técnico de los 3225 fotogramas que lo componen, la cama sobre la que se fotografía pasa a convertirse en espacios muy variados: cama, calle, tren, mar, etc. Los almohadones son nubes o escalones que baja, los calcetines son peces de las profundidades marinas que sueña la protagonista. Desde este punto de vista es mucho más rico que el spot de Telefónica. Los objetos cotidianos del clip de "Her Morning Elegance" se transforman en otra cosa y la animación es una estrategia narrativa para incitar a quien mira el video a hacerle caso a su imaginación. Mientras que la razón reconoce los objetos, la imaginación se deleita en su metamorfosis. En ese reconocimiento de la realidad y su mutación en un mundo quimérico se crea un puente facilitado por el despliegue visual y los artificios narrativos del clip. En ese aspecto el clip musical de Orien Lavie está muy en sintonía con el mundo quimérico desplegado por las fotos de Holleben y por el clip de "The Ribs of a Broken Umbrella". Lo cotidiano se convierte en algo diferente gracias al extrañamiento visual que provoca la animación. El hecho de que las fotos de Holleben estén protagonizadas por niños es un indicador de la capacidad metamórfica que emplean los niños en su juego gracias a su imaginación. La realidad se enriquece gracias a esta actividad recreadora de la mente infantil que es concretada por la técnica del stop-motion. El número de visitas que obtuvo en YouTube este video de Orien Lavie es un indicativo del enorme éxito. Ese éxito lo hace visible. Por eso establecer los parecidos entre el spot de Telefónica y el vídeo de "Her Morning Elegance" era algo que no debía extrañar. Sin embargo, haciendo un balance podría decirse que el spot no posee esa capacidad transformadora de la realidad. Es más bien una interpretación narrativa de fotos de Holleben, algo que el propio fotógrafo realiza en sus clips de animación.

Visto así, las fronteras entre el arte y otros discursos parecen difuminarse amparadas por el proceso en el que la cultura actual parece organizarse. Las metamorfosis continuas, derivadas de los cambios de soportes, formatos e intenciones que borran, suplantan y reconstruyen la autoría crean continuos vínculos conformando un laberinto infinito. El entramado semiótico denominado cultura se hace así cada vez más denso. En cierto modo Séneca veía algo parecido cuando concebía al escritor 
como una abeja que libaba de diferentes flores para construir su discurso. Montaigne en el siglo XVI afirmaba que no hacíamos otra cosa que entreglosarnos y La Bruyere dictaminaba que todo parecía estar dicho y uno siempre llegaba demasiado tarde. Todo aquello parece haberse hecho mucho más complejo sobre todo teniendo en cuenta cómo la interferencia de lenguajes oculta cambios en la intención con que se utiliza. La retórica publicitaria ya no persigue una persuasión explícita; se ha ocultado bajo disfraces muy diversos; acapara y absorbe todo tipo de ejemplos que, si bien podían no pertenecer a nadie o ser fragmentos de textos artísticos, acaban por ser anexionados a su mundo y convertirse en una marca registrada ${ }^{26}$. La democratización del lenguaje a través de la red tiene su contrapartida en esas apropiaciones realizadas por las marcas comerciales a través de su marketing ${ }^{27}$. La publicidad, además, se vale de técnicas diversas que incrementan su valor estético y su contenido emocional desplazando su contenido retórico-persuasivo por un uso estético que busca el placer. Se explican así estrategias como son los casos del branding content o la utilización deliberada del storytelling(Salmon, 2008) para crear unafilosofía en torno a un producto. Los mensajes se convierten en algo híbrido no sólo

\footnotetext{
${ }^{26} \mathrm{Al}$ y Laura Ries escriben: "More and more consumers, too, see advertising as an art form rather than a communication vehicle. [...] People look at advertising the way read a novel or watch a television show. The get involved in characters, situations, and plots without the least bit of motivation to act out any of the parts, including buying the product". (2002: 18).

27 Se ha destacado la importancia de las marcas en el mundo postmoderno: "Corporate trademarks are key symbols in a postmodern signifying culture" (Coombe, 1998: 56). Las marcas pueden a través de estos dispositivos retóricos publicitarios absorber materiales de diversa índole para construir su imagen. Sin embargo, no se permite el proceso contrario. Ese proceso asimétrico de apropiación nos lleva a plantearnos quién posee el lenguaje, las palabras y las imágenes. Aun así tenemos ejemplos estupendos en el uso artístico de los logos de las marcas como es el cortometraje de animación titulado Logorama de François Alaux y Hervé de Crécy (2009). Desde una ideología corrosiva podría destacarse el uso de los logos en el cómic de Marcos Prior y Danide Fagocitosis (2011) que ya en su portada muestran una desconstrucción visual del logo de mastercard a través de una metáfora visual. Aun con todo podríamos pensar que los logos son una propiedad privada. Véase el capítulo "Intellectual Property" de Ashely Packard (2013: 161 y ss.) y también las páginas de Naomi Klein "La piratería publicitaria. Los anuncios bajo ataque" de su libro No logo (2001: 329-362). En otro ámbito, que afecta a las identidades culturales, la práctica de la apropiación no deja de tener un talante manifiestamente polémico. Baste con recordar todo el revuelo de opiniones levantadas en torno al éxito de "Malamante" de Rosalía, que ha sido objeto de críticas por realizar una apropiación cultural de estilemas y modos expresivos del flamenco gitano. En el debate existe una mezcla de factores tan diversos de legitimidad cultural, pertenencia a un grupo, prácticas mercantiles y poéticas fusionadoras con afán renovador. Todo depende desde la posición en la que se contemple el fenómeno.
} 
por su naturaleza hipercodificada sino también por la capacidad que tienen, una vez manipulados, de asumir nuevas funciones en nuevos contextos. El vídeo-clip de una versión musical puede convertirse en un potente anuncio de la canción original que versionea; un vídeo viral nos puede conducir a una película de anime japonesa, algunos anuncios televisivos funcionan a modo de trailers que nos envían a una página web en la que se puede ver todo el anuncio que asume las maneras de un pequeño corto cinematográfico. Esos textos híbridos pertenecen a una suerte de retórica diluida, camuflada bajo apariencias puramente artísticas que vuelven al espectador un target vulnerable emocionalmente hablando o bien despiertan en él un carácter lúdico que ayudan a recordar un producto determinado. La descripción somera de este continuo trasiego de sonidos e imágenes nos ha permitido ver ese doble comportamiento (colonización y depredación) a través del cual el lenguaje se regenera en una cadena infinita de mensajes. Este itinerario azaroso comenzaba en el terreno musical. Tanto es así que puede verse en lo musical el magma de un sistema de ordenación semiótica que he denominado cultura sampleada. Igualmente, productiva puede ser la idea de concebir en el seno de esa cultura sampleada la música como un lenguaje primario que puede recombinarse e integrarse en otros lenguajes activando así la capacidad mezcladora. Frente a ese lenguaje primario surgen otros que podían denominarse terminales con una capacidad de absorción muy grande - la publicidad es un buen ejemplo - que marcan un límite en esa actividad sampleante y productiva. Tienden a ser un punto de llegada: marcan una frontera difusa entre el uso estético del lenguaje y su finalidad práctica.

En la nueva Torre de Babel no todos los lenguajes se ensamblan armónicamente ni estos permanecen estables, pero sí que en su ansiedad saturan de sentido cada expresión para borrar fronteras en un proceso de enlaces cada vez complejo y vertiginoso. Aquellas fronteras se convierten en puertas giratorias por las que transitan los lenguajes destinados a ser y no ser un arte efímero. 


\section{REFERENCIAS BIBLIOGRÁFICAS}

ALBIÑANA, R. (2008). Manos [anuncio publicitario para la campaña Duo, de Telefónica]. Productora Albiñana Films.

ALLEM, G. (2000). Intertextuality. London: Routledge.

ANÓNIMO (2007). "Datf Hands", vídeo viral en YouTube: https://www. youtube.com $/$ watch? $v=K 2 c Y W f q--N w$ [10/01/2019].

BAUMAN. Z. (2013). La cultura en el mundo de la modernidad líquida. México: Fondo de Cultura Económica.

BEEBE, R. (2007). "Paradoxes of Pastiche: Spike Jonze, Hype Williams, and the Race of Postmodern Auteur." En Medium Cool. Music Videos From Soundies to Cellphones, R. Beebe \& J. Middleton (eds.), 303-327. London: Duke University Press.

BOURRIAUD, N. (2005). Postproduction: Culture as Screenplay: How Art Reprograms the World. New York: Lukas \& Stermberg.

BRUNS, A. (2007). "Produsage: Towards a Broader Framework for Userled Content Creation". En Proceedings: Creative and Cognition. G. Fisher, E. Giaccardi, M. Esenberg \& L. Candy (eds.), 99-106. New York: Association for Computing Machinery (también en https:/leprints.qut.edu.au/6623/1/6623.pdf [22/03/2019]). (2008). Blogs, Wikipedia, Second Life and Beyond: From Production to Produsage. New York: Perter Lang.

BURGESS, J. \& GREEN J. (2009). YouTube. On line Video Participatory Culture. Cambridge: Polity Press.

COOMBE, R. (1998). The Cultural Life of Intellectual Properties. Authorship, Appropriation and the Law. London: Duke University Press.

ERSTAD, O. (2008). "Trajectories of Remixing. Digital Literacies, Media Production, and Schooling." En Digital Literacies: Concepts, Politics and Practices. C. Lankshear \& M. Knobel (eds.), 177-202. New York: Peter Lang.

EVANS, D. (ed.) (2009). Appropriation. Cambridge: MIT Press.

INGEBORD, H. (2001). Pastiche. Cultural Memory in Art, Film, Literature. Bloomington: Indiana University Press. 
INGLIS, I. (2012). "Music into Movies. The Film of the Song" En $A$ Companion to Literature, Film and Adaptation. D. Cartmell (ed.), 312-329. Wiley: Blackwell.

JASZI, P. (ed.) (1994). The Construction of Authorship: Textual Appropriation in Law and Literature. London: Duke University Press.

JENKINS, H. (2008). Convergence Culture. La cultura de la convergencia de los medios de comunicación. Barcelona: Paidós.

JUVAN, M. (2008). History of Poetics of Intertextuality. Purdue: Purdue University Press.

KNOBEL, M. y LANKSHEAR, C. (2011). "Remix: la nueva escritura popular". Cuadernos Comillas 1, 105-126 (también en http://everydayliteracies.net/files/8_Knobel_Lankshear.pdf [15/01/2019]).

LESSIG, L. (2008). Making Art and Commerce Thrive in the Hybrid Economy. Nueva York: The Penguin Press.

MANOVICH, L. (2005): "Remixability and Modularity", http://manovich. net/content/04-projects/046-remixability-and-modularity/43 article_2005.pdf [20/01/2019].

(2007): "What Comes after Remix?", http://manovich.net/ content/04-projects/057-what-comes-after-remix/54_article_2007. pdf [20/01/2019].

MARTÍNEZ FERNÁNDEZ, J. E. (2001). La intertextualidad literaria. Madrid: Cátedra.

MOORFIELD, V. (2005). The Producer as Composer: Shaping the Sounds of Popular Music. Massachusetts: MITT.

NAVARRO, D. (ed.) (1997): Intertextualité. Francia en el origen de un término y el desarrollo de un concepto. La Habana: Casa de las Américas / Embajada de Francia en Cuba.

PACKARD, A. (2013). Digital Media Law. Wiley: Blackwell.

PlASKETES, G. (ed.) (2010). Play it Again. Cover Songs in Popular Music. Farnham. Burlington: Ashgate.

REYNOLDS, S. (2012). Retromania. Pop Culture's Addiction to Its Own Past. London: Faber \& Faber.

RIES, A. \& RIES L. (2002). The Fall of Advertising \& the Rise of PR. New York: Harper Collins Publishers.

RODRÍGUEZ, R. y MORA, K. (2002). Frankenstein y el cirujano plástico. 
Una guía multimedia de semiótica de la publicidad. Alicante: Universidad de Alicante.

RODRIGUEZ FERRÁNDIZ, R. (2008). "La publicidad como industria cultural". Pensar la publicidad II.1, 19-36 (también en http:// revistas.ucm.es/index.php/PEPU/article/view/PEPU0808120019A [14/03/2019]).

(2012). "Benjamin, BitTorrent, Bootlegs: Auratic Piracy Cultures? http://ijoc.org/index.php/ijoc/article/view/1187/711 [14/03/2019].

ROOT, D. (1996). Cannibal Culture: Art, Appropriation and Commodification of Difference. Westwiew: Boulder.

SALMON, Ch. (2008). Storytelling. La máquina de fabricar historias y formatear las mentes. Barcelona: Península.

SANDERS, J. (2006). Adaptations and Appropriation. London \& New York: Routledge.

SHUTE, G. (2015): Concept Albums. S.l.: Investigations Publishing.

SIBILLA, G. (2010). "It's the End of Music Videos as we know them (but We Feel Fine). Death and Resurrection of Music Videos in the YouTube Age". En Rewind, Play and Fast Forward. The Past, The Present and Future of the Music Video, Henry Keazor \& Thorsten Wübbena (eds.), 225-232. Bielefeld: Transcript Verlag.

SNICKARS, P. \& VONDERAU, P. (2009). The YouTube Reader. National Library of Sweden.

STRANGELOVE, M. (2010), Watching YouTube. Extraordinary Videos by Ordinary People. Buffalo / London / Toronto: University of Toronto Press.

SWEETING, A. (2004). Cover Versions. Singing Other People's Songs. London: Pimlico.

TAKENOUCHI, K. (2003). Interstella 5555. The 5tory of 5ecret 5tar 5ystem. Toei Animation Company / Daft Life Ltd. Co.

VERNALLIS, C. (2004). Experiencing Music Video. Aesthetics and Cultural Context. New York: Columbia University Press.

(2010). "Music Video and YouTube: New Aesthetics and Generic Transformations. Case Study-Beyoncé's and Lady Gaga's Video Phone." En Rewind, Play and Fast Forward. The Past, The Present and Future of the Music Video, Henry Keazor \& Thorsten Wübbena (eds.), 233-260. Bielefeld: Transcript Verlag.

VON HOLLEBEN, J. (2006). Flying Dreams. London: The Photographers' 
Office.

(2009). The Ribs of a Broken Umbrella, vídeo-clip musical para el grupo Bell X1.

WELCHAM, J. (2001). Art After Appropriation. Essays on Art in the 1990s. New York: Routledge.

YOUNG, J. (2011). “Appropriation and Hybridity”. En The Routlegde Companion to Philosophy and Music, T. Gracyk \& A. Kania (eds.), 176-187. Oxon / New York: Routledge.

Recibido el 27 de enero de 2019.

Aceptado el 21 de marzo de 2019. 